\title{
Identifikasi Potensi Pangan Lokal untuk Penganekaragaman Produk Pangan Kota Balikpapan
}

\author{
Gozali $^{1 *}$, Bambang Jati Kusuma ${ }^{2}$ \\ ${ }^{1,2}$ Politeknik Negeri Balikpapan, \\ *gozali@poltekba.ac.id
}

\begin{abstract}
The purpose of this study was to determine the potential of superior local food in the Balikpapan City. The method used in this research is descriptive method. Data collection techniques using the location survey and institutional survey methods. The identification of local food potential in the Balikpapan City in this study in terms of the food sector in terms of availability. Based on the results of data analysis that has been carried out in the city of Balikpapan, there are about 12 (twelve) types that are widely cultivated by farmers, namely: sweet corn, papaya, banana, cempedak, lai / durian fruit, dragon fruit, sweet potato / wood, pineapple, salak, and rambutan. Although some other plants are also found, but relatively few in number, such as tomatoes, cucumber, guava, and others. The existence of local food in the Balikpapan City area has the potential to be developed into various food products.
\end{abstract}

Keywords: potential food, local food, superior food, food diversification

\begin{abstract}
Abstrak
Tujuan penelitian ini adalah untuk mengetahui potensi pangan lokal unggulan yang ada di Kota Balikpapan. Metode yang digunakan dalam penelitian ini adalah metode deskriptif. Teknik pengumpulan data dengan metode survey lokasi dan survey kelembagaan. Identifikasi potensi pangan lokal di Kota Balikpapan dalam penelitian ini diinjau dari sektor pangan ditinjau dari aspek ketersediaan.Berdasarkanhasilanalisis data yang telahdilakukan, komoditi pertanian yang ada di Kota Balikpapan terdapat sekitar 12 (dua belas) jenis yang banyak dibudidayakan para petani yakni: jagung manis, pepaya, pisang, cempedak, buahlai/durian, buah naga, ubi jalar/kayu, nanas, salak, dan rambutan. Meskipun beberapa tanaman lain juga dijumpai namun jumlahnya relative sedikit, misalnya tomat, timun, jambu biji, dan lain-lain. Keberadaan panganlokal yang ada di wilayah Kota Balikpapan sangat berpotensi untuk dikembangkan menjadi berbagai produk pangan.
\end{abstract}

Kata kunci: potensi pangan, pangan lokal, pangan unggulan, diversifikasi pangan.

\section{Pendahuluan}

Undang-Undang No. 18 Tahun 2012 tentang Pangan mengamanatkan bahwa Pemerintah berkewajiban mewujudkan penganekaragaman konsumsi pangan untuk memenuhi kebutuhan gizi masyarakat sesuai dengan potensi dan kearifan lokal untuk mewujudkan hidup sehat, aktif, dan produktif.Masalah pangan bukan merupakan masalah sekarang saja tetapi sudah merupakan masalah di masa lampau dan juga akan menjadi masalah di masa akan datang. Karena pangan merupakan kebutuhan dasar manusia yang paling utama untuk mendukung dan aktivitas fisiologis (Pawiroharsono, 2013).

Dalam Peraturan Menteri Pertanian tentang Gerakan Percepatan Penganekaragaman Konsumsi Pangan berbasis Sumberdaya Lokal disebutkan bahwa pangan lokal didefinisikan sebagai pangan baik sumber karbohidrat, protein, vitamin dan mineral yang diproduksi dan dikembangkan sesuai dengan potensi sumberdaya wilayah dan budaya setempat. Sementara itu, pangan olahan adalah makanan atau minuman hasil proses dengan cara arau metode tertentu 
dengan atau tanpa bahan tambahan (Badan Ketahanan Pangan, 2009).Pangan adalah segala sesuatu yang berasal dari sumber hayati produk pertanian, perkebunan, kehutanan, perikanan, peternakan, perairan, dan air, baik yang diolah maupun tidak diolah yang diperuntukkan sebagai makanan atau minuman bagi konsumsi manusia, termasuk bahan tambahan pangan, bahan baku pangan, dan bahan lainnya yang digunakan dalam proses penyiapan, pengolahan, dan atau pembuatan makanan atau minuman. sedangkan pangan lokal adalah makanan yang dikonsumsi oleh masyarakat setempat sesuai dengan potensi dan kearifan local (Karafir, dkk. 2004). Sedangkan menurut Husain (2004), pangan lokal adalah pangan yang diproduksi setempat (suatu wilayah/daerah tertentu) untuk tujuan ekonomi dan atau konsumsi.Sedangkan penganekaragaman pangan adalah makanan atau minuman yang dikonsumsi dari berbagai sumber pangan.

Kota Balikpapan adalah salah satu kota di Provinsi Kalimantan Timur, Indonesia. Kota ini memiliki luas wilayah 503,3 km² (Dinas Perkebunan, 2019). Balikpapan memiliki potensi pangan lokal yang luar biasa besar akan tetapi walaupun stok pangan tersedia, potensi tersebut belum termanfaatkan dengan baik. Masalah yang saat ini ada adalah perhatian pemerintah dan masyarakat terhadap pengembangan potensi pangan lokal masih sangatlah kurang, seringkali sudah muncul tetapi lebih banyak dalam seminar dan lokakarya serta pernyataan-pernyataan yang menjanjikan tetapi tidak berlanjut dalam implementasi. Walaupun telah ada Perpres untuk percepatan diversifikasi pangan, namun implementasinya mengalami hambatan. Perpres ini seolah-olah menjadi mandate dari Kementerian Pertanian, sementara institusi yang lainnya kurang mendukung hal tersebut. Banyak kebijakan pangan yang justru paradok dengan kebijakan diversifikasi konsumsi pangan, seperti adanya kebijakan raskin, kebijakan produksi beras yang dominan dan mengabaikan produksi pangan local, dan lainnya (Ariani, dkk. 2013).Hal ini mungkin disebabkan baik pemerintah daerah maupun masyarakat dalam berbagai profesi belum terlalu menyadari bagaimana pentingnya pengembangan potensi pangan lokal untuk penganekaragaman pangan serta mewujudkan ketahanan pangan nasional untuk kedepannya.

Berdasarkanuraiandi atas dan oleh karena itu perlu dikaji secara mendalam terkait dengan pangan lokal unggulan di Kota Balikpapan yang menitik beratkan pada penggalian potensi khusunya tanaman pangan yang berbasis pangan lokal untuk penganekaragaman pangan lokal. Selain untuk melihat kondisi dan potensinya, hasil kajian ini dapat berfungsi sebagai komponen perencanaan, penelaah dalam pengambilan kebijakan terkait pengembangan potensi produk pangan lokal di Kota Balikpapan.

\section{Metodologi}

Metode penelitian yang digunakan dalam penelitian ini adalah metode deskriptif kualitatif. Metode deskriptif dalam penelitian ini digunakan untuk memaparkan atau menggambarkan masalah yang sedang dihadapi yakni gambaran mengenai potensi pangan lokal unggulan di Kota Balikpapan.

Teknik pengumpulan data dalam penelitian adalah survey lokasi dan survey kelembagaan. Data yang dikumpulkan terdiri atas dua jenis, yaitu data primer dan sekunder. Data primer diperoleh langsung dari hasil survey lokasi wilayah Kota Balikpapan dan analisis. Sedangkan, data sekunder diperoleh secara tidak langsung yang bersumber dari literatur atau dokumen kajian kelembagaan pada dinas terkait di Kota Balikpapan yakni Dinas Pangan, Dinas Pertanian dan Perikanan, Dinas Koperasi, Usaha Mikro, Kecil, Menengah dan Perindustrian serta Dinas Perdagangan.Data yang diperoleh selanjutnya dianalisis dan disajikan dalam bentuk tabel. 


\section{Hasil dan Pembahasan}

\subsection{Identifikasi Potensi Pangan Lokal di Kota Balikpapan}

Berdasarkan hasil identifikasi dari sektor tanaman pangan ditinjau dari aspek ketersediaan, komoditi pertanian yang ada di wilayah Kota Balikpapan terdapat sekitar 12 (sepuluh) jenis yang banyak dibudidayakan para petani, meskipun beberapa tanaman lain juga dijumpai namun jumlahnya relatif sedikit, misalnya tomat, timun, jambu biji, lai, cempedak. Komoditi pertanian yang memberikan kontribusi cukup signifikan terhadap pertumbuhan ekonomi masyarakat adalah jagung manis, nanas, papaya, singkong, dan pisang.

Tabel 1. Luas panen tanaman pangan (tanaman bahan makanan) menurut jenisnya di Kota Balikpapan tahun 2018

\begin{tabular}{llc}
\hline \multirow{2}{*}{ No. } & \multicolumn{1}{c}{ Jenis } & Luas Panen $(\mathrm{Ha})$ \\
\cline { 3 - 3 } & & Jan - Des \\
\hline 1. & Jagung manis & 380 \\
2. & Pepaya & 126 \\
3. & Pisang & 23.5 \\
4. & Cempedak & 0.12 \\
5. & Nanas & 0.18 \\
6. & Ubi kayu & 271 \\
7. & Ubi Jalar & 27 \\
8. & Rambutan & 19 \\
9. & Lai & 12 \\
10. & Salak & 8 \\
11. & Durian & 11 \\
12. & Buah Naga & 0.13 \\
\hline
\end{tabular}

Dari tabel 1 terlihat bahwa luas panen tanaman pangan di Kota Balikpapan didominasi jagung manis kemudian ubi kayu berikutnya adalah pisang dan ubi jalar hampir sama, hal ini menunjukkan bahwa Kota Balikpapan adalah salah satu penghasil jagung.

Tabel 2. Produksi tanaman pangan (tanaman bahan makanan) menurut jenisnya di Kota Balikpapan tahun 2017

\begin{tabular}{llc}
\hline \multirow{2}{*}{ No. } & \multicolumn{1}{c}{ Jenis } & Produksi (ton) \\
\cline { 3 - 3 } & & Jan - Des \\
\hline 1. & Jagung manis & 30.400 \\
2. & Pepaya & 48.000 \\
3. & Pisang & 7.355 \\
4. & Cempedak & 2.252 \\
5. & Nanas & 13.255 \\
6. & Ubi kayu & 8.834 \\
7. & Ubi Jalar & 350 \\
8. & Rambutan & 420 \\
9. & Lai & 645 \\
10. & Salak & 2.400 \\
11. & Durian & 550 \\
12. & Buah Naga & 735 \\
\hline
\end{tabular}

Dari tabel 2 dapat dilihat bahwa produksi berbagai jenis tanaman didominasi papaya dan jagung manis, kemudian nanas dan ubi kayu. Hal ini menunjukkan bahwa tanamantersebut punya potensi untuk dikembangankan sebagai pangan lokal unggulan. 


\subsection{Penganekaragaman Produk Pangan Kota Balikpapan}

Berdasarkan hasil identifikasi potensi pangan, Kota Balikpapan memiliki tanaman pangan dengan berbagai jenis dan rasa. Adanya berbagai tanaman berpotensi untuk diolah dan dikembangkan menjadi produk pangan dengan cita rasa khas.

Tabel 3. Penganekaragaman Produk Pangan

\begin{tabular}{|c|c|c|}
\hline Pangan Lokal & $\begin{array}{c}\text { Penganekaragam } \\
\text { Produk Pangan }\end{array}$ & Sumber \\
\hline Jagung manis & Es krim, yoghurt, dan pudding jagung & Maherwati (2018) \\
\hline Pepaya & Es krim, manisan, jelly drink & Miranti, M., dkk. (2016) \\
\hline Pisang & Brownis, dodol, pudding, es krim & Purwati \& Rofik, A. (2019) \\
\hline Cempedak & Mandai, cempedak goreng, cake cempedak. & Kumparan food (2018) \\
\hline Nanas & Yohgurt nanas, selai, sari buah nanas, nutria & Rahayu, M.H. (2016)\& Lesbani \\
\hline Ubi kayu/Ubi Jalar & jelly. & $(2015)$ \\
\hline Buah Naga & Keripik, stik, kue kering, roti, dan mie. & Ginting, dkk. (2006) \\
\hline Lai/durian & Dodol, selai, & Farida (2017) \\
\hline \multirow[t]{2}{*}{ Salak } & Bakpao & \\
\hline & Selai, manisan, keripik, dodol & Hapsari, dkk. (2008) \\
\hline
\end{tabular}

Tabel 3 menunjukkan pangan lokal yang ada wilayah Kota Balikpapan dan potensi untuk dikembangkan menjadi produk pangan dengan berbagai macam jenis dan rasa khasnya. Penganekaragaman pangan denganmemanfaatkan potensi produk pangan lokaladalah salah satu alternatif yang dinilai sangattepat oleh karena berbagai alasan, yakni: (1)dapat meningkatkan nilai tambah sumberpangan lokal; (2) dapat melestarikan sumberdayahayati; dan (3) mempermudah akses kepadakonsumen dan mengurangi biaya transportasi (Pawiroharsono, 2013).

\section{Kesimpulan}

Ditinjau dari aspek produksi (ketersediaan), terindikasi bahwa pangan lokal yang tersedia dan teridentifikasi di wilayah Balikpapan sesuai keanekaragaman hayati yang ada dari hasil perkebunan meliputi: jagung manis, nanas, pepaya, nagka/cempedak, pisang, ubi jalar, ubi kayu, rambutan, lai dan salak. Pangan lokal tersebut berpotensi untuk dikembangan menjadi produk pangan yang beragam dan bermutu juga bermanfaat untuk mendukung perekonomian Kota Balikpapan.

\section{Saran}

Dalam rangka mengidentifikasi potensi pangan lokal di daerah serta untuk mendapatkan data yang akurat, valid dan dapat dipertanggung jawabkan, maka tim peneliti masih memerlukan waktu dan dana untuk survey langsung kelapangan yang menjadi objek penelitian.DiharapkanPemerintah Kota Balikpapan dapat mengembangkan kapasitas dalam peningkatan produksi pangan secara mandiri dan berkelanjutandan memanfaatkan potensi pangan lokal unggulan untuk pengembangan produk pangan sesuai kebutuhan dalam meningkatkan daya saing produk pangan unggulan berbasis keanekaragaman lokal.

\section{Ucapan Terimakasih}

Penelitian ini didanai oleh DIPA Poltekba Tahun Anggaran 2018 dengan nomor kontrak: 20/PL32.13/SPK-LT/2018.Terimakasih kami sampaikan kepada Pusat Penelitian dan Pengabdian kepada Masyarakat Politeknik Negeri Balikpapan atas dukungan dana yang diberikan sehingga penelitian ini bisa terlaksana. 


\section{Daftar Pustaka}

Ariani, M., Hermanto, Hardono, G.S., Sugiarto, Wahyudi, T.S. (2013). Kajian Strategi Pengembangan Diversifikasi Pangan Lokal. Laporan Kegiatan Kajian Isu-Isu Aktual Kebijakan Pembangunan Pertanian 2013.Pusat Sosial Ekonomi Dan Kebijakan Pertanian Badan Penelitian Dan Pengembangan Pertanian.

Badan Ketahanan Pangan. (2009). Peraturan menteri Pertanian: Gerakan percepatan penganekaragaman Konsumsi Pangan Berbasis Sumberdaya Lokal.

Dewan Ketahanan Pangan. (2012). Undang-Undang Nomor 18 tahun 2012 Tentang Pangan

Dinas Perkebunan Provinsi Kaltim. (2019). Potensi Daerah Kota Balikpapan.

Ginting, E., Antarlina, S.S., Utomo, S.J., Ratnaningsih. (2006). Teknologi Pasca Panen Ubi Jalar Mendukung Diversifikasi Pangan Dan Pengembangan Agroindustri.Jurnal Litbang Pertanian. http://dx.doi.org/10.21082/bul\%20palawija.v0n11.2006.p15-28

Hapsari, H., Djuwendah, E., Karyani., T., (2008). Peningkatan Nilai Tambah dan Strategi Pengembangan Usaha Pengolahan Salak Manonjaya. Jurnal Agricultura, 19, (3),208-215. Retrieved from https://doi.org/10.24198/agrikultura.v19i3.1005.

Husain. (2004). Konsep dasar potensi pengembangan pangan spesifik lokal di Provinsi Papua. hlm. $33 \square$ 42. Dalam. Y.P. Karafir, H. Manutubun, Soenarto, Y. Abdullah, B. Nugroho, dan M.J. Tokede (Ed.). Prosiding Lokakarya Nasional Pendayagunaan Pangan Spesifik Lokal Papua. Kerja Sama Universitas Papua dengan Pemerintah Provinsi Papua.

Karafir, Y.P. Manutubun, H., Soenarto, Y., Abdullah, Y., Nugroho, B., dan Tokede, M.J. (2004). Prosiding Lokakarya Nasional Pendayagunaan Pangan Spesifik Lokal Papua. Provinsi Papua, 33-42

Kumparan Food. (2018). 5 Olahan Lezat Buah Cempedak yang Bisa Kamu Buat di Rumah. Retrived from https://kumparan.com/@kumparanfood/5-olahan-lezat-buah-cempedak-yang-bisa-kamu-buat-dirumah

Lesbani, A. (2015). Pembinaan industri kecil sari buah nanas dan nutri jelly sebagai pengolahan alternatif dari buah nanas dengan kandungan gizi yang tinggi di desa beti inderalaya selatan kab. ogan ilir. Jurnal Unsri, $\quad 3, \quad$ (1). $\quad$ Retrieved http://ejournal2.unsri.ac.id/index.php/jpsriwijaya/article/view/2153.

Maherwati, Sarbino, (2018). Diversifikasi produk olahan jagung manis sebagai upaya peningkatan nilai tambah Bagi petani jagung di daerah wisata Pasir Panjang-singkawang. Jurnal Untan, 1, (1), 17-25.

Miranti, M., Wardatun, S., Wiendarlina. (2016). Diversifikasi produk olahan limbah papaya California Inferior pada kelompok tani tirta mekar, desa Mekarsari, kecamatan rancabungur, bogor. Prosiding Seminar Nasional Hasil-Hasil PPM IPB, 239-249.

Pawiroharsono, S. (2013). Revitalisasi Penganekaragaman Pangan Berbasis Pangan Lokal. Jurnal Pangan, 22, (1), 77-90. https://doi.org/10.33964/jp.v22i1

Purwati., Rofik, A. (2019). Diversifikasi pangan berbasis pisang rutai untuk Meningkatkan Daya saing pangan local. Abdimas Mahakam Journal, 3, (1), 50-57.

Rahayu, H.M. (2016). Pelatihan Diversifikasi Olahan Yogurt Berbahan Dasar Buah Lokal. Jurnal Unmuh. 6 (1). Retrieved from http://dx.doi.org/10.2940/pena2016.61.214. 